\title{
Aspidistra Production and Use ${ }^{1}$
}

Robert H. Stamps ${ }^{2}$

FAMILY: Convallariaceae ( Liliaceae)

\section{GENUS: Aspidistra}

SPECIFIC EPITHET: caespitosa, elatior, lurida

CULTIVARS: 'Ginga' ('Starry Night'), 'Jade

Ribbons', 'Milky Way', 'Okame' ('Variegata')

There are from eight to over thirty species of Aspidistra depending on which taxonomist is queried. At the current time, there are only a few species that are fairly readily available for sale and there is some controversy as to which species are which. Therefore, buyers should make sure that what they are ordering is what they want.

These plants are slow growing, evergreen, rhizomatous, perennial herbs native to East Asia. They have simple leaves with entire (smooth) margins and parallel veins.

The most common species is Aspidistra elatior, the cast-iron or bar-room plant of the Victorian era (Figure 1). It is renowned for its durability and ability to survive under adverse conditions: low light, high heat, poor soil, and drought. The specific epithet

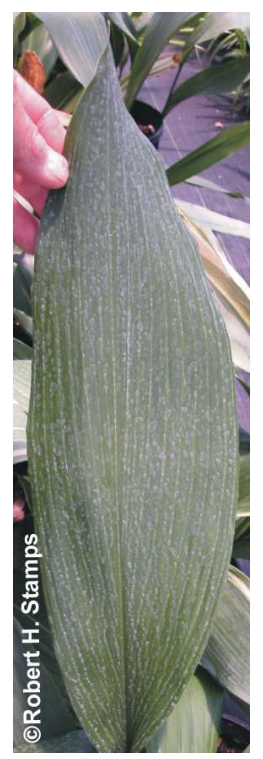

Figure 1. Aspidistra elatior leaf.

elatior is derived from elat meaning exalted, lofty, high and ior meaning more so, to a greater degree. A. elatior has glossy, dark green leaves that can be $3 \mathrm{ft}$ $[0.9 \mathrm{~m}]$ in length $(1 \mathrm{ft}$ petiole [leaf stalk] and $2 \mathrm{ft}$ blade) and 5 inches [13 cm] wide. A. elatior 'Okame' (also soldas A. elatior 'Variegata') has similarly sized leaves that are irregularly marked with light green and white streaks (Figure 2). This attractive cultivar

1. This document is ENH890, one of a series of the Environmental Horticulture Department, Florida Cooperative Extension Service, Institute of Food and Agricultural Sciences, University of Florida. Original publication date August 4, 2003. Visit the EDIS Web Site at http://edis.ifas.ufl.edu.

2. Robert H. Stamps, Professor of Environmental Horticulture and Extension Cut Foliage Specialist, Mid-Florida Research and Education Center, 2725 Binion Road, Apopka, FL.

The use of trade names in this publication is solely for the purpose of providing specific information. UF/IFAS does not guarantee or warranty the products named, and references to them in this publication does not signify our approval to the exclusion of other products of suitable composition. All chemicals should be used in accordance with directions on the manufacturer's label. Use pesticides safely. Read and follow directions on the manufacturer's label.

The Institute of Food and Agricultural Sciences is an equal opportunity/affirmative action employer authorized to provide research, educational information and other services only to individuals and institutions that function without regard to race, color, sex, age, handicap, or national origin. For information on obtaining other extension publications, contact your county Cooperative Extension Service office. Florida Cooperative Extension Service/Institute of Food and Agricultural Sciences/University of Florida/Christine Taylor Waddill, Dean. 
is highly sought after but, unfortunately, is slower and harder to grow than the green form. Its leaves tend to be highly variable even on the same plant and some will revert to all green over time. If green leaves are not removed, they will out-compete the variegated ones and take over.

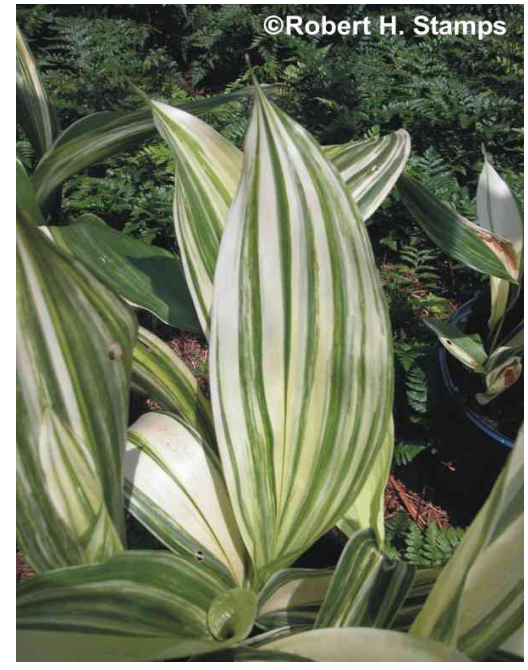

Figure 2. Aspidistra elatior 'Okame'.

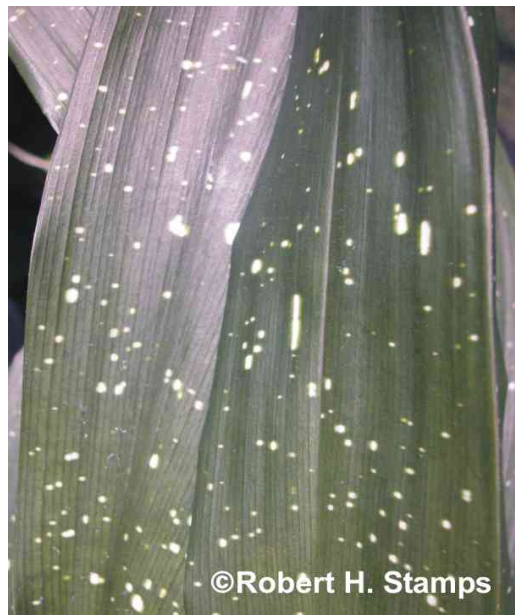

Figure 3. A. lurida 'Ginga/Starry Night'.

Less readily available but becoming increasingly common is A. lurida 'Ginga' (Figure 3). 'Ginga' may also be sold as 'Starry Night' and has shiny green leaves covered with cream- to white-colored streaks and spots. 'Ginga' leaves can grow as long as those of A. elatior but are narrower, usually less than 3 inches $[8 \mathrm{~cm}]$ wide. The leaves of the cultivar 'Milky Way' ('Minor') are also covered with ivory- to white-colored dots and dashes like 'Ginga/Starry Night'; however, the blades are shorter (less than 2 feet $[0.6 \mathrm{~m}])$, narrower $(3$ inches $[8 \mathrm{~cm}])$ and are not glossy. Some references list 'Milky Way' as being a cultivar of A. elatior.

Another Aspidistra just becoming available is $A$. caespitosa. The cultivar 'Jade Ribbons' has narrow $(1 / 2$ inch $[1.2 \mathrm{~cm}])$ leaves that may reach 24 inches [0.6 m] in length (Figure 4). Like other Aspidistra, this plant seems to be fairly slow growing.

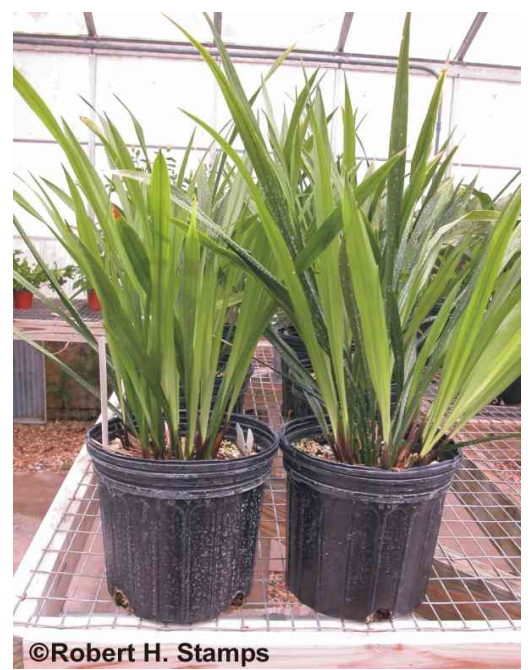

Figure 4. A. caespitosa 'Jade Ribbons'.

Aspidistra are valued for their foliage, and their flowers often go completely unnoticed because they are cryptically colored and borne at the soil line. Interestingly, since mollusks (slugs and snails) are fairly common pests found feeding on Aspidistras, it is reported that they are the pollinators of Aspidistra flowers.

\section{Floral Design, Landscape and Interiorscape Use}

\section{Floral Design Use}

Aspidstra leaves are reportedly non-toxic and extremely long-lasting. They make good line (linear) materials in floral arrangements. Due to their large size, A. elatior leaves are used as mass item/filler/background material in large, contemporary arrangements. A. caespitosa 'Jade Ribbons' leaves can be used as linear elements in much the same fashion as leaves of Liriope muscari 'Evergreen Giant' (known in the trade as lily "grass" or Florida beargrass). In addition, Aspidistra leaves can be rolled, twisted, tied, and pinned into all kinds of shapes (Figure 5) and used as form material. 
Furthermore, leaves can be used fresh, dried, or preserved and are available year-round

\section{Landscape Use}

Aspidistra are commonly used as ground covers in shade gardens since they can tolerate light to very heavy shade. Aspidistra cannot tolerate full sunlight but can tolerate drought and competition from tree roots. They can also be used as accent, edging, or container plants. Aspidistra are reportedly deer-resistant plants and are listed as being non-toxic to pets and people. Old leaves will need to be pruned out periodically.

\section{Interiorscape Use}

Many dark Victorian homes were decorated with Aspidistra. Although not often offered as acclimatized houseplants due to their slow growth rate, Aspidistra are some of the most durable of all plants for interiorscaping. As mentioned under landscape use, they are listed as non-toxic.

\section{General Cultural Requirements}

Aspidistra can be grown successfully in containers or in the ground.

\section{Temperature:}

AHS Plant Heat Zones: $12-4$

USDA Plant Hardiness Zones: 7b-11 (A. caespitosa, A. elatior), 8-11 (A. lurida)

Aspidistra can be grown outdoors in warm temperate to tropical zones where temperatures rarely fall much below about $23^{\circ} \mathrm{F}\left[-5^{\circ} \mathrm{C}\right]$.

Growing media: Aspidistra are tolerant of a wide range of soils and potting media as long as they are well-drained. However, they do best in media containing organic matter with high cation exchange capacities and good water-holding capacity (but still well-drained). The media should be kept evenly moist but not wet.

Fertilizer: Although Aspidistra are tolerant of a wide range of nutrient conditions, there is interest from commercial growers in determining how to optimize production of this slow-growing plant. In an experiment conducted at the Mid-Florida Research and Education Center (MREC) in Apopka, Florida, yield (number, fresh weight, average leaf weight) of A. elatior leaves from plants growing in ground beds of fine sand soil (Tavares-Millhopper) increased with increasing nitrogen application rate up to about 200 lbs/acre/yr [224 kg/ha/yr] (Figure 6). The nitrogen source was a $19 \mathrm{~N}-2.6 \mathrm{P}-10 \mathrm{~K}$ controlled-release fertilizer with macro- and micronutrients (Woodace $19 \mathrm{~N}-6 \mathrm{P}_{2} \mathrm{O}_{5}-12 \mathrm{~K}_{2} \mathrm{O}$, Vigoro Industries).

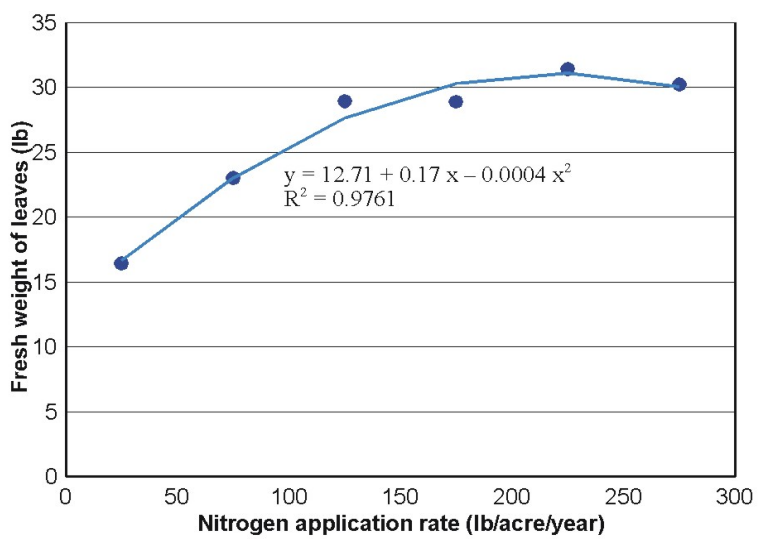

Figure 6. Effects of fertilizer application rate on $A$. elatior leaf production.

Since variegated Aspidistra is the most visually striking and highest in demand, another experiment was conducted at the MREC to determine the effects of fertilizer rate on its growth. In this experiment, the plants were grown in \#3 [9.5-liter] pots containing a Florida sedge peat:pine bark:builders' sand (6:3:1) potting medium. A $19 \mathrm{~N}-2.6 \mathrm{P}-10 \mathrm{~K}$ controlled-release fertilizer (Osmocote ${ }^{\circledR} 19 \mathrm{~N}-6 \mathrm{P}_{2} \mathrm{O}_{5}-12 \mathrm{~K}_{2} \mathrm{O}$, The Scotts Company) applied at four nitrogen application rates from 400 to $1,600 \mathrm{lb} / \mathrm{acre} / \mathrm{yr}$ [ $4481,792 \mathrm{~kg} / \mathrm{ha} / \mathrm{yr}$ ] was used in this experiment. Yield (leaf numbers, fresh weights, and average weights) of variegated leaves was not affected by fertilizer application rate nor was overall yield of both variegated and green leaves. After $33 / 4$ years, $45 \%$ of the plants had produced harvestable green leaves.

Avoid fertilizers containing high levels of fluoride because, like many other members of the Convallariaceae (Liliaceae) family, Aspidistra are somewhat fluoride sensitive. In addition, care must be taken when applying granular fertilizers (and other granular materials as well) so that they do not 
get trapped inside the tubes formed by the rolled-up emerging, new leaves.

Light: Aspidistra grow best under considerable shade. For 'Milky Way', plant establishment in the ground in central Florida was equally good under $50 \%$ and $80 \%$ shade. These shade levels are approximately equivalent to maximum photosynthetically active radiation levels of 1,194 and $478 u \mathrm{~mol} \cdot \mathrm{m}^{-2} \cdot \mathrm{s}^{-1}$ [ 6,209 and 2,486 ft-candles], respectively. Under $30 \%$ shade the plants barely survived, and in full sun the plants essentially died. Leaf lengths and fresh weights, as well as vase life, increased with increasing shade level and peaked under $80 \%$ shade. While vase life was excellent under $30 \%$ shade (43 days), it was $46 \%$ longer for fronds grown under $80 \%$ shade (Figure 7).

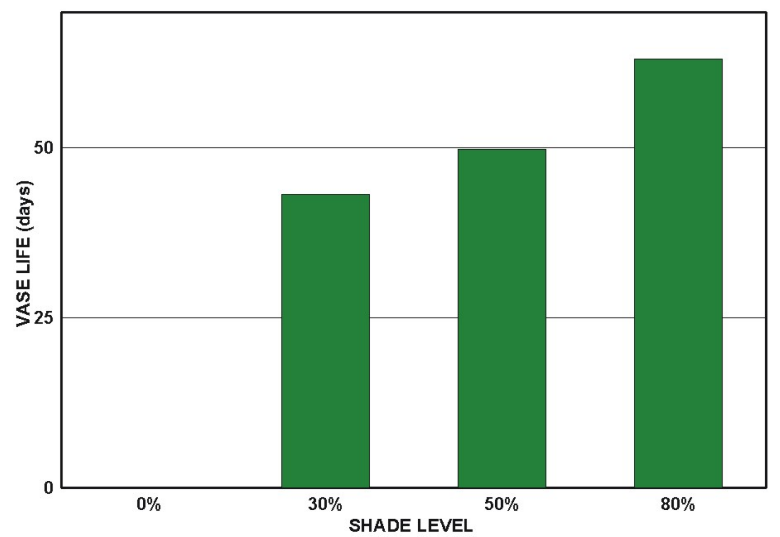

Figure 7. Production shade level affected subsequent vase life of Aspidistra 'Milky Way' leaves.

Numbers and fresh weights of variegated $A$. elatior 'Okame' ('Variegata') leaves were $58 \%$ and $66 \%$ greater under $63 \%$ shade compared to $73 \%$ shade, probably due to the higher light levels compensating for the reduced chlorophyll content of the variegated leaves. Shade level had no effect on production of green leaves in that experiment.

Water: Once established, Aspidistra are tolerant of droughty conditions but prosper under evenly moist conditions. They are also listed as moderately salt tolerant. Overhead irrigation may help reduce mite problems but can increase foliar diseases.

Planting: Aspidistra plants appear to transplant well starting from almost any size including single rhizome nodes. For cut foliage production, plants can be grown in the ground or in pots, and plants are usually spaced quite closely. This can maximize production if foliar diseases, insects and mites can still be adequately controlled. Initial spacings for landscape plantings are 12 to 18 inches [0.3 $0.5 \mathrm{~m}$ ].

Propagation: Aspidistra are most commonly propagated by division of the rhizome (underground stem) (Figure 8). This method of propagation helps assure that propagules will have the characteristics of the original plant. Plants can be started from each underground node. Some Aspidistra are also started from seed but seed is not readily available.

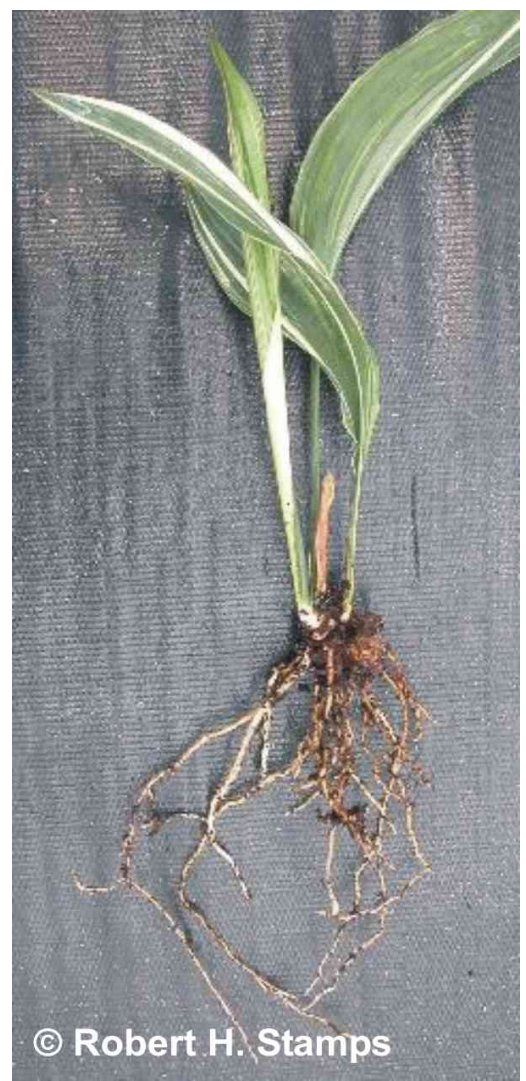

Figure 8. Aspidistra are typically propagated by dividing the rhizome.

\section{Common Cultural Problems}

Pests: Although relatively trouble-free, Aspidistra are subject to a number of pests.

\section{Insects:}

Caterpillars (larval stages of various moths) 
Symptoms - Worm-like creatures crawling on the leaves. Rows of holes in lines perpendicular to the length of the leaf (Figure 9).

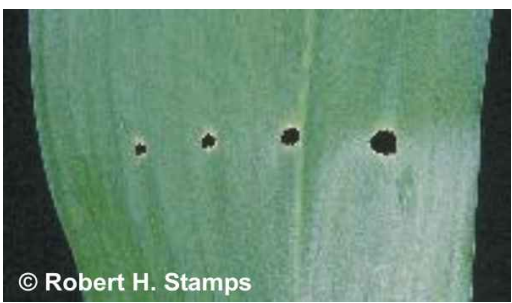

Figure 9. Typical damage caused when a caterpillar feeds on an emerging leaf while it is still curled up.

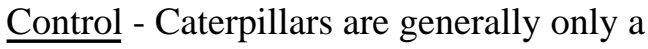
problem in outdoor, as opposed to shadehouse or greenhouse, situations. The caterpillars often fall from other plants (for example, oak trees) on to the aspidistra and then try to eat the Aspidistra leaves. Aspidistra is apparently not a very favored host for most caterpillars, so the damage is rarely extensive unless there is a large population of caterpillars that fall into the Aspidistra plantings. There are many biological and chemical insecticides that are effective on caterpillars and many have been used safely on Aspidistra. Application of insecticides when caterpillars are small increases chances of obtaining satisfactory control. See http://edis.ifas.ufl.edu/IG012 for a listing of products available for controlling caterpillars. Prior to widespread use, test new products for crop safety by making multiple applications to a small block of representative plants and then checking the treated plants for damage.

Scale (fern scale, Pinnaspis aspidistrae) is frequently found feeding on A. elatior.

Symptoms - Small white (adult male) and hard brown (adult female) bumps on the leaves. The female scale are about 1/12th of an inch [2.1 mm] in length and pear-shaped. Males are more numerous than females and have parallel sides and a distinct longitudinal ridge (Figure 10). Preadults are smaller than adults, oval and yellowish to orangish in color.

Control - Oils should not generally be used on Aspidistra leaves being grown for cut foliage use because they can penetrate into the leaves and cause a "water-soaked" mottling that is unacceptable to florists (Figure 11). Systemic insecticides are preferred because it is difficult to penetrate the waxy

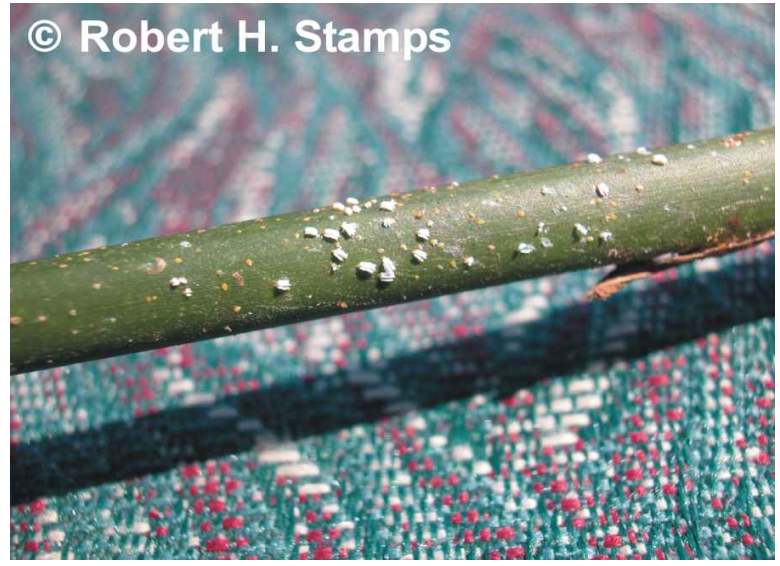

Figure 10. Fern scale on Aspidistra petiole.

outer coating of the scale. Few materials are specifically labeled for use on Aspidistra. See http://edis.ifas.ufl.edu/IG012 for a listing of products available for controlling scales. Prior to widespread use, test new products for crop safety by making multiple applications to a small block of representative plants and then checking them for damage.

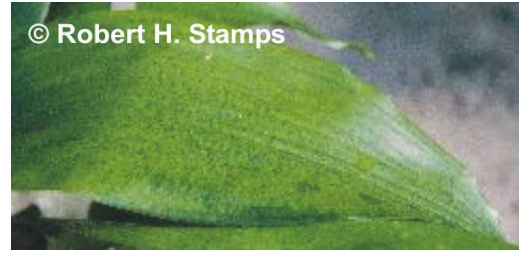

Figure 11. Oils can penetrate Aspidistra leaves and cause unsightly mottling.

\section{Mites:}

\section{Two-spotted spider mites (Tetranychus spp.)}

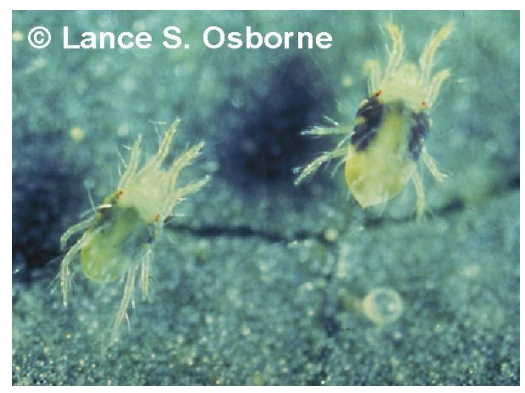

Figure 12. Two-spotted spider mites.

Symptoms - These mites are very small, have dark areas on each side of the body, and typically are found on the undersides of leaves (Figure 12). When present, they can be detected by beating leaves against a light-colored surface and looking for these eight-legged creatures running across the surface. 
Unless actively scouted for, two-spotted spider mites are often not detected until plants are severely infested. Mite feeding causes foliage to become speckled, may induce yellowing and ultimately can lead to leaf tip dieback (Figure 13).

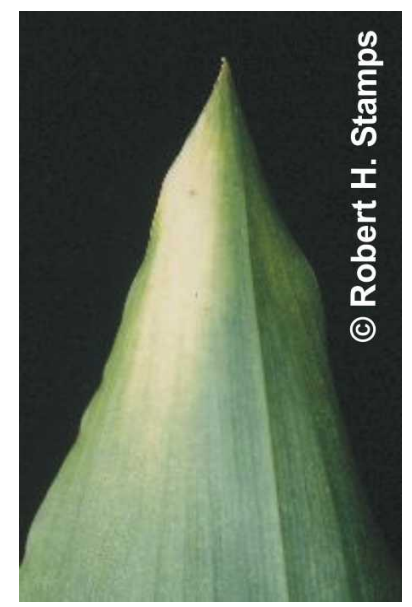

Figure 13. Mite feeding can lead to severe damage to Aspidistra leaves.

Control - Regular scouting for mites can facilitate the detection of infestations before they become severe and widespread. Systemic miticides are preferred because it is difficult to get thorough coverage of all leaf surfaces. However, few materials are specifically labeled for use on Aspidistra.

Miticides that coat and suffocate all the developmental stages (e.g., oils) can also be effective. However, oils can cause mottling (see Scale for description) so they should be used very carefully if the Aspidistra leaves are being grown for cut foliage use. See http://edis.ifas.ufl.edu/IG012 for a listing of products available for controlling mites. Prior to widespread use, test new products for crop safety by making multiple applications to a small block of representative plants and then checking for phytotoxicity.

\section{Mollusks:}

\section{Slugs and snails}

Symptoms - Gouged out areas along the surface of the petiole. Irregular holes with smooth edges on leaves (similar to the damage pictured in Figure 9). Glossy slime (mucus) trails on leaves. Slugs and snails present.
Control - Do not overwater the crop. Since slugs and snails are mainly nocturnal, scout at night or early in the day for slime trails and live slugs and snails. Removal by hand can work for small plantings or light infestations. There are methiocarb-based sprays and metaldehyde or metaldehyde/carbaryl-based slug/snail baits that can aid in control; however, like many pesticides, they should be used judiciously. Baits should not be used where children, pets, and wildlife can get to them. Baits based on iron phosphate have the advantage of being safer but may not be quite so effective. Apply baits after irrigating or following a rain event because that is when the slugs and snails will be most active. Baiting is less effective during hot, dry, or cold periods because snails and slugs are less active then. If the baits can be covered with boards or other shelters that act as natural hiding places for slugs and snails, their effectiveness may be improved. These shelters should be removed when baits are not present in them. Do not water heavily for at least 3 or 4 days after bait placement. See http://edis.ifas.ufl.edu/IG012 for a current listing of products available for controlling mollusks.

\section{Diseases:}

\section{Fungal}

Leaf spot - Although quite a number of fungal pathogens have been isolated from leaves of Aspidistra, leaf spot due to Fusarium spp. seems to be the predominant problem.

Symptoms - Spots are initially water-soaked and form on immature leaves. Spots then turn tan to red-brown and may have a bright yellow halo.

Control - Keep foliage as dry as possible by using cultural practices that avoid the use of overhead irrigation, irrigate when the foliage will dry most rapidly, and protect the foliage from wetting due to precipitation. Sanitation, i.e. removal of infected foliage, may help. In addition, fungicides labeled for controlling Fusarium may be helpful.

\section{Root and Petiole Rot (Sclerotium rolfsii)}

Symptoms - The first signs of infection are dark-brown lesions on the stem at or just beneath the 
soil level. Those symptoms usually go unnoticed and it is the yellowing and death of the leaves that draws attention to the problem. The fungus produces white, fluffy mycelium on infected tissues and the soil. The mustard seed-like sclerotia that are produced on the mycelium are round and white when immature and become dark brown to black when mature.

Control - Use a well-drained growing medium and keep it evenly moist but not saturated with water. Start with clean plant material and avoid the introduction of this pathogen. If infection is found, remove infected plants. Do not over-irrigate. Biological control agents and chemical fungicides labeled for controlling Sclerotium rolfsii may be helpful.

\section{Root and Petiole Rot (Fusarium solani)}

Symptoms - Leaves rot off at the base of the petiole, roots become black rather than white.

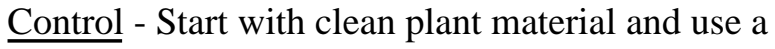
well-drained growing medium. Keep the medium evenly moist but not overly wet. If medium drainage is poor, correct the problem or move the plants. Fungicides labeled for controlling Fusarium may be somewhat helpful but any problems with the medium drainage and lack of adequate aeration should be addressed or the problem will likely recur.

Note: Mention of a commercial or proprietary product or chemical does not constitute a recommendation or warranty of the product by the author or the University of Florida, Institute of Food and Agricultural Sciences, nor does it imply its approval to the exclusion of other products that may also be suitable. Products should be used according to label instructions and safety equipment required on the label and by federal or state law should be employed. Users should avoid the use of chemicals under conditions that could lead to ground water contamination. Pesticide registrations may change so it is the responsibility of the user to ascertain if a pesticide is registered by the appropriate state and federal agencies for an intended use.

\section{Non-pest problems}

Lichens: When Aspidistra are grown under heavy shade the leaves may become coated with lichens (Figure 14). Lichens are plants composed of algae and fungi living together symbiotically (the association is beneficial to both organisms). This is a cosmetic problem and is not a disease. Lichens are slow growing and their presence on Aspidistra leaves is an indication that the leaves are quite old. Even though the lichens can be wiped off, the leaves probably should not be harvested since they are well past their prime.

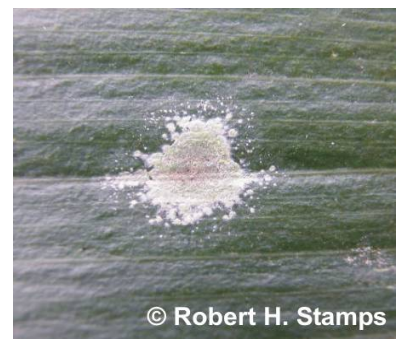

Figure 14. Lichens can develop on old Aspidistra leaves that were not harvested in their prime.

Pollen: When Aspidistra are grown under trees the leaves may become coated with pollen (Figure 15). This is also a cosmetic problem and not a disease. As with lichens, pollen can be wiped off the leaves.

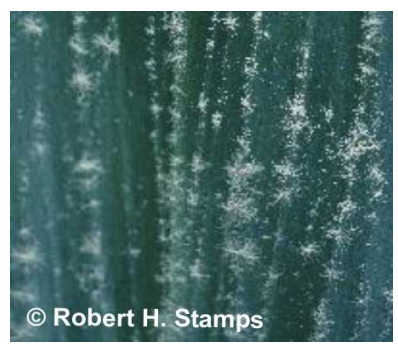

Figure 15. While not harmful, pollen can be an unsightly problem on Aspidistra grown under trees.

\section{Harvesting and Postharvest Considerations}

Harvesting and Handling: For cut foliage use, Aspidistra leaves are harvested with clippers and are frequently bundled ten per bunch using rubber bands. Leaf lengths vary with cultivar and markets; however, larger and variegated leaves generally command higher prices than smaller and/or all green leaves. Leaves of cut and potted Aspidistra should be 
protected from being mechanically damaged during handling. Wounding the leaves can lead to fungal infection and tissue damage.

Storage and Shipping: Harvested leaves should be stored and shipped at temperatures around $40^{\circ} \mathrm{F}$ $\left[4^{\circ} \mathrm{C}\right]$. Stems will hold for weeks in waxed corrugated fiberboard containers. Acclimatized containerized Aspidistra elatior plants can be shipped for two weeks if held at $50-55^{\circ} \mathrm{F}\left[10-13^{\circ} \mathrm{C}\right]$.

Vase life: Typically, stems of Aspidistra will last in arrangements for a month or longer.

Problems: Aspidistra are shade plants and if they are planted in high light to full sun conditions, they will decline due to photobleaching and other problems.

\section{Selected References}

Anonymous. Tropical Products Transport Handbook, Potted flowering and foliage plants. United States Dept. of Agriculture. 20 May 2003. $<$ http://amsdev.ams.usda.gov/tmd/Tropical/ pottedplants.htm>.

Ascher, A.A. 1988. Variegated plants. Flower \& Garden 32(5):44-45.

Bailey, L. H. 1917. The Standard Cyclopedia of Horticulture. $2^{\text {nd }}$ ed. The MacMillan Company, London.

Benz, M. B.and J. L. Johnson. 1986. Flowers: Geometric Form. San Jacinto Publishing, College Station, TX.

Dehgan, B. 1998. Landscape Plants for Subtropical Climates. The University Press of Florida, Gainesville, FL.

Gilman, E. F. 1996. Betrock's Florida Plant Guide. Betrock Information Systems, Hollywood, FL.

Griffith, L. P., Jr. 1998. Tropical Foliage Plants - A Grower's Guide. Ball Publishing, Batavia, IL.

Hunter, N. T. 1994. The Art of Floral Design. Delmar Publishers, Albany, NY.
Huxley, A. (Editor-in-Chief). 1992. The New Royal Horticultural Society Dictionary of Gardening. The Stockton Press, New York.

McMillan, R. T. , Jr., R. L. V. Hei, and W. R. Graves. 1999. Southern blight (Sclerotium rolfsii): a new disease of cast iron plant. Proc. Florida State Hort. Soc. 111:206-207.

Merrow, A.W. and Black, R.J. 1993.

Enviroscaping to conserve energy: Ground covers for central Florida. Univ. of Florida/IFAS, Florida Coop. Ext. Serv. Circular EES-38.

Scace, P. D. 2001. The Floral Artist's Guide: A Reference to Cut Flowers and Foliages. Delmar/Thomson Learning, Albany, NY.

Stamps, R. H. 1988. Major Florida cut foliage crops classified according to floral design and landscape usage. Proc. Florida State Hor. Soc. 100:179-180.

Stamps, R. H. 1995. Effects of shade level and fertilizer rate on yield and vase life of Aspidistra elatior 'Variegata' leaves. J. Environ. Hort. 13(3):137-139.

Stamps, R. H. 1997. Effects of production shade levels on leaf/stem size and vase life of three herbaceous perennials. Proc. Florida State Hort. Soc. 109:309310.

Stamps, R.H. 1999. All-around aspidistras. Ornamental Outlook 8(10):25-26.

Stamps, R. H., F. P. Beall, B. W. Beall, J. P. Carris, M. R. Jackson, S. M. Motley, P. S. Smith, and N. L. Freeman. 1995. Effects of shade level and radiation freezes on survival and growth of ground cover plants. Proc. Florida State Hort. Soc. 107:432-436.

Watkins, J. V.and T. J. Sheehan. 1969. Florida Landscape Plants: Native and Exotic. The University Presses of Florida, Gainesville, FL. 